\title{
Redesign Of The Undergraduate Business Curriculum: The Way Forward, A Paradigm Shift
}

Priscilla Berry, Jacksonville University, USA

\begin{abstract}
The need to reform the undergraduate business curriculum was in evidence before $9 / 11$ and is more imperative since the stock market disintegration beginning in December 2007. The stakeholders will not tolerate the old methods of functional teaching for business school graduates. Graduates must be work ready and the challenges to business schools are evident in declining enrollments and loss of funding trends which will be evident for the next decade. What we do now will be how we operate for the next ten years. Schools cannot invest in professional development of faculties and redesign of courses in a casual manner. This article poses the process business model as one pattern for redesign and explores the implementation of this model with specific examples of pedagogical methods for the redesign of the undergraduate business curriculum. An example for implementation of the approach to include the experiential element which begins to breakdown silo teaching in a three-hundred level undergraduate Management class is included in the appendix.
\end{abstract}

Keywords: Undergraduate Business Curriculum, Management Curriculum, Business Process Model, Silo Teaching

\section{INTRODUCTION}

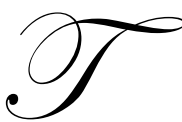

his paper describes an ongoing effort to bring the concept of business process more completely into the undergraduate core business curriculum. The research looks briefly at the background of how we got to where we are and how that model sustained itself for such a long time in education. The paper examines the pedagogical reasons for changing to a process model and takes for granted that all business schools must follow the AACSB standards for accreditation and specifically section C.1.3.e which says, "The curriculum should integrate the core areas and apply cross-functional approaches to organizational issues." We take cross functional to mean that individuals come together from multiple disciples to create and solve challenges within the corporate structure. The process model is the acknowledgement, identification, and incorporation of the core business competencies for a real world business process woven in a hands-on style into the classroom experience. This paper includes in the appendix the outline for a specific project for a three-hundred level Management class that can be reproduced and modified for other disciples in the undergraduate business curriculum.

\section{DEMAND FOR THE PROCESS MODEL}

The phrase "The Way Forward" is, of course, the mantra adopted by the Ford Motor Company, albeit, too late for Ford. It seems obvious, considering world conditions, that this is the mantra that business education must embrace now and sooner rather than later. What is wonderful about the academic world is that it is somewhat protected, unlike the corporate arena, from the slings and arrows of the outrageous fortunes of money and its pursuit. At least this has been the case in the past. However, today, that time to wait, to contemplate and to experiment in the crucible of the classroom and move slowly is over. The trickle down, up, or over effects from the massive paradigm shifts throughout the world are yet to be fully comprehended and the whole world is currently in a reactionary posture. However, one thing is crystal clear, life will not be the same and things have changed. Education is now 
more than challenged, it is demanded to be accountable, transparent, and to grow leaders with a high level of integrity, as well as specific (not general) skills and targeted knowledge. This research will focus on outlining the needed shift to a process-centered business curriculum, experiential in design, and fully integrated in concept and execution.

The business curriculum of the $21^{\text {st }}$ century must reflect the process driven organizations that focus on a new breed of consumer and supplier. Even though Campbell, Heriot and Finney defend the use of silo learning (2006) it is clear that the days of teaching in isolation are over. Campbell argues, articulately, that the demand to match the undergraduate business curriculum to the corporate environment is much over rated. He contends that the changes that need to be made in the undergraduate curriculum are pedagogical in nature and not curriculum based. The point made here is that the cost, human and monetary, in the complete overhaul of the curriculum is enormous and a waste of resources. The position is that the changes that need to come to keep pace with the demands of the principle stakeholders - employees and students- are pedagogical in nature and the classroom instructor is the lynchpin to this endeavor. We need to, in short according the Campbell, alter how we teach in our functional areas, not what we teach. The argument is that an employer would rather have an entry level employee with some depth of business knowledge rather than an employee with concepts of integration and no depth of knowledge.

Campbell's reasoning is faulty; however, and the challenge to Campbell's thesis is that to leave what we teach in the classroom unaltered and only change the pedagogy and how we deliver is to fail to see the elephant in the room. The process model that organizations are using today requires that we model our curriculum to eliminate the isolation of block learning (Walker, 2000). The business curriculum must eliminate the silo process or structure of courses to eliminate the impact of silo teaching on the process of learning. We must integrate the curriculum and show how the accounting class relates to the business communications class, and we can only do that when we roll back the veil on the real world. Students resist this because they really do not want the real world when they are in the college classroom. For many, the reason they are in school is to wait on going into the real world, and they resist as long as possible seeing the experience as preparation for the business arena. This is the shift that the business curriculum must provide through an integrated curriculum.

Talking about the Ford Companies as the voice of management past seems appropriate since we have seen it die right before our eyes. Everything in business going forward will be consumer oriented. The old arrogant days of Ford boasting, "if we build them, they'll buy them" are over for good. Corporations whether they want to care or not must "care" about the end-user and focus on what is desired. The business students must come to understand how what they are learning applies to the business process, and the curriculum must be redesigned with new technologies and pedagogical tools and most importantly the instructional delivery and content must make the shift to integration (Olson, 1993).

This paper presents a rationale and the imperative for an integrated business curriculum in terms of delivery, design, and resources.

\section{We may first remember how we got here and why we are changing.}

Adam Smith in the Wealth of Nations (1776) taught us about the division of labor and others like Sloan and Ford executed this teaching in the creation of the assembly line. Most business schools have been organized like business around a post war model of core division established in companies like General Motors which had such great leaders as General McNamara. Nelson discusses the classic Harvard model calling it the "Hollow Harvard Core" which sets up the traditional core approach. (1990). There should never be any diminishing of what has gone before us in business or the academic world; we can only stand as tall as the shoulders on which we stand and these leaders helped shape a great nation and a strong teaching culture. The culture of the division of labor also supported the silo learning concept in schools of business. This worked for many years, successfully.

What is demanding change from these old models is the dominance of the consumer voice and the rise in technology. Basically, the consumer is more educated with more access to information and they demand complete and competent answers. Because of technology, they demand the answers now. Simply read a Tom Friedman 
treatise or look at the numbers on the use of cell phones world wide and please....let's just Google Earth to get an answer or product we want.

Silo teaching only works for a business environment where things are predictable. Function based companies were the norm in the $20^{\text {th }}$ century. A bureaucracy works well if all things are fixed in the business environment because things are predictable. Technology has changed this forever. Even the businesses that have been slower to innovate cannot avoid this necessity. Innovation demands ideas and ideas must come from many places. The current curriculum and philosophy about teaching in a business school leaves the graduate woefully unprepared for the world of work. They have a very narrow view of what business is about, little experience or knowledge of how cross functional teams operate and for what purpose. Most current business curriculums deliver a function focused curriculum with silo learning. While corporations have moved quickly to the use of cross functional teams for leadership, program implementation, product delivery, schools of business remain mired in function based teaching (Cannon, Klein, Koste, Magal, 2004)

\section{COURSE DELIVERY}

Course delivery is probably the most difficult hurtle to an integrated curriculum because it involves faculty and reworking of course descriptions. Every course description or syllabi must contain a reference to the strategic forces involved with every business decision: ethics, technology, diversity, and organizational behavior. This material has to become part of the delivered course content. Faculties are narrowly trained with most of faculty having degrees that delivered functional content to them in the first place, some century ago. To overcome this, the faculty has to have leadership via the Dean, if the Dean does not get it, the business faculty cannot move forward. Dean George Stevens at Kent State University's College of Business Administration and the Graduate School of Management discusses the role of deanship and points to Academic Leadership as the greatest priority for the $21^{\text {st }}$ century. Deans must be change agents and must persuade and convince faculty to change and do something in a different way. He goes on to say the world of academia must change dramatically if it is to survive and be relevant. Deans see this, but faculties often do not. Competition from virtual universities and the increasing demands of the marketplace for more "vocational" degrees may spur some realization for the need for change. Stevens discusses the juxtaposition of change in academia as opposed to change in corporations. The first changes at an evolutionary pace and the second at a revolutionary one. The demand from the corporate world is clear, and if we intend to keep colleges with specialty centers alive and well, the academic world will shift to delivering courses that are cross functional and relevant (Stevens, 2000).

\section{COURSE DESIGN}

Business schools must move away from dividing the courses along strict knowledge lines and create an integrated curriculum. Each course in the business program must show a connection to the other courses. Accounting and Economics courses must have ethics and leadership and communication integrated into the content. Richard Cosier, AACSB (a business school accrediting body) board member and Dean of Purdue's Krannert School of Management, echoes the words of Nobel Laureate Lech Walesa "ethics should serve as the grounds for all solutions we impose in this era" (Cosier p. 53, 2008). We cannot teach any functional area in a business school today, given the world milieu, without grounding it in ethics. The Qualitative courses must "see" the skills needed for leadership as belonging in their content and the same with communication skills which must be presented as an integral part of all course content. In short, we must include in all the courses in the business core all of a company's processes, products, and people.

One method for implementation of integration and cross functional curriculum is through the use of Enterprise Resource Software that has been around since the 1980s. There are several vendors for these software packages but the lead vendor is SAP. (Wagner, Najdawi, Otto, 2001) The enterprise resource planning system software is described by Cannon, et.al. in the Journal of Education for Business (2004). This enterprise resource planning package and its implementation is explained also by Peslak in the Journal of Information Systems Education (2005). This type of software application is typical of software integration systems that can be employed in the core curriculum to unite the functional areas. 
One somewhat easier or first step path than the more involved shift proposed by Cannon and explained by Peslak is to create cross functionally taught course. Ideally, course content could be delivered in a team taught environment. The communications professor could do a segment in each class on communication or a course could be designed that was communication across the functions. At the least, a capstone course should be implemented at the undergraduate level that connects the dots for students and combines all the functional areas of the curriculum in one course centered on knowledge execution with leadership skills.

Another excellent way to focus individualized content into functional content areas is to have students select their industry of interest and even the corporation for which they would like to work. Initially, when students declare a major, they also select an industry and within each functional area course, students are assigned a project that researches the accounting, marketing, management, etc information within that industry. Included in the appendix is one sample of an undergraduate communications project that is experiential in nature while addressing the functional content of a business communications class.

\section{CONCLUSION}

More than how we accomplish the transition in practical terms is the need to make the paradigm shift in attitude and understanding. We must first as faculty believe that the system needs redesign and then believe that we can deliver graduates who are more competitive and attractive to employers, one of our principle stakeholders. Faculties need the leadership of a Dean with vision and understanding of the resources required to reinvent the course design around business process not isolated content. Faculty may need professional development activities which can be costly. More partnerships with local businesses need to be in place, and the Dean must know how to make these partnerships happen. Partnerships are only possible if the business faculty members are meeting the needs of business. This is something of a challenge because faculties are seldom rewarded for going outside the classroom or the research arena-out into the "real" world. The reward structure must be altered to acknowledge the change requirements of business and the academic environment. The process based curriculum considers the total picture of a company, and this is most evident when partnerships are in place between business school and corporations and when faculties are fully engaged with the corporations for research and for course design. One way to begin this process is to have collaboration and integration within the faculty structure.

Corporations want courses that offer experiential content and not content for the sake of content. Most businesses today want the soft skills such as communication, leadership and team building along with interpersonal skills for all entry level employees. They need people who can be part of a team and get along within the work force. There is great emphasis placed by employers today on assessment for emotional intelligence. They need employees who are not a risk, mentally or physically. Corporations have elaborate training capacity, and they do not expect knowledge or strong content when students graduate. Content in isolation is not of value anyway to a large entity. Corporations want students who are work ready which means that they are strong students dedicated to life long learning. If students have learned qualitative skills for decision making while solving a real problem for a company or have learned the skills through a corporate case study, then the skill has application immediately for the business environment.

Business process forms, or should form, the basis for cross functional thinking which is how our students need to be taught. Courses should be designed with cross functional activities fully integrated into core courses. There is a pressing need for students to actually see how work is done which moves us completely away from compartmentalized environments and possibly even out of the standard classroom setting.

\section{FINAL RATIONALE}

There are many voices giving strength to the demand to redesign the business curriculum, and the voices have reached critical mass. One such articulation by James Canton in his book The Extreme Future: The Top Trends that will Reshape the Future in the Next Twenty Year (2007) states the following:

1. The current education system has failed to complete its most vital and strategic mandate: prepare the workforce for the future. 
2. Education does not have the leadership, guts, or vision to reinvent itself.

3. Most schools, kindergarten through college, are not in sync with changes in the marketplace-more competitive, more complex, more global, more innovation-driven.

4. Without educational change, more companies will outsource to find skilled talent offshore, creating unemployment in the U.S.

5. Teachers are not to the problem. Pay teachers double and retain them for the Innovation Economy. Measure their performance, hire the best, and fire the slackers.

6. Political leaders have lacked the courage to create a Future-Ready national innovation, curriculum, more science, more innovation, more high-tech, a more global outlook, and more entrepreneurial skills.

7. We are teaching kids about the past. We need to teach the kids about the future. How to survive the Extreme Future (p. 107).

\section{AUTHOR INFORMATION}

Dr. Berry is a graduate of the University of Mississippi with degrees in English, Literature, and Humanities and select Corporate Clients include: Communications Planning Corp, Children's Haven, Americall, LDC, DuPont, Interline, Duval County School Board, CSX, the Jacksonville Symphony, and the Army Corp of Engineers. She was a guest professor at the University of Caen in France lecturing to international postgraduates on Doing Business in a Global Economy.

Dr. Berry is currently researching, publishing, and speaking on the Glass Ceiling for Women, issues of academic integrity, and other pedagogical subjects. Most recently she created a Financial Literacy Curriculum for corporate women, and is passionate about the cause of Financial Literacy for Women.

\section{REFERENCES}

1. Campbell, N.D., Heriot, K.C. \& Finney, R. Z. (April, 2006). In Defense of Silos: An Argument Against The Integrative Undergraduate Business Curriculum. Journal of Management Education, 30, 316- 333.

2. Cannon, D.M. Klein, H.A., Koste, L.L., \& Magai, S.R. (November/December 2004) Curriculum Integration Using Enterprise Resource Planning: An Integrative Case Approach. .Journal of Education for Business, 80(2), 93-102.

3. Canton, J. (2007). The Extreme Future: The Top Trends that will Reshape the World in the next 20 Years. Penguin Group, USA.

4. $\quad$ Cosier, R. (September/October 2008). Ethical Objectives. Biz Ed, 52-57.

5. Nelson, C. (September, 1990). Harvard's Hollow Core. The Atlantic Monthly. 54.

6. Peslak, A.R. (summer, 2005). A Twelve-Step, Multiple Course Approach to Teaching Enterprise Resource Planning. Journal of Information Systems Education, 16, 147-156.

7. Stevens, G.E. (summer, 2000). The Art of Running a Business School in the New Millennium: A Dean's Perspective. Sam Advanced Management Journal, 1-7.

8. Wagner, P.W., Najdawi, M.K., \& Otto, James (2000). An Empirical Investigation into the Impact of ERP Training on Cross-Functional Education. Journal of the Academy of Business Education,1, 107. Retrieved December 21, 2008 from http:// http://www.abe.villanova.edu/proc2000/n107.pdf.

9. Walker, K. \& Black, E. L. Reengineering the undergraduate business core curriculum: aligning business schools with business improved performance. Business Process Management Journal. 6 (3), 194-203. 


\section{APPENDIX}

The Final Exam for MGT 308 begins day one of the course and it has three parts: A research paper, documented APA Style, on the Industry of your choice, a profile of the corporation you intend to work for when you graduate, and a personal interview with a practicing professional in the career filed of your selection. You will need to gather five samples of professional business writing that are characteristic of the business writing in the career field you have selected for this long formal researched report. The following information is to be used in the preparation for this project.

I. Set an Interview with a practicing professional, not a relative, or a person on campus. Ideally, this individual would hold a career position you intend to pursue. Select an individual who-occasionally or as a routine part of their duties - formally writes to a specific audience for a variety of specific purposes. When you make the appointment, ask for five samples of writing, which he/she considers representative samples of the work required in their position. It is wise to discuss your selection with me and to have me give you advice on how to proceed with this part of the project. Remember that business people are busy people and can not set appointments the day before your project is due. You must calculate lead time for this assignment.

II. Set up a mutually agreeable time to interview the person. Be clear about your expectation and be specific about what you require.

III. Before you go on the interview: Complete the research for the paper and write a status report on the industry: Fully documented and complete with internal citations. This research information will contain answers to the following questions:

- Health and size of the Industry in terms of the National Economy. This will include financial data: Relevant data that shows the size, importance, relationship of the Industry within the National Economy

- Legal and Ethical Concerns, Challenges: Industry Environment

- Technology Data: Relevant data that examines the technology challenges and advances

- Diversity Challenges: Relevant data on the Industry and Diversity ( what does the labor market look like in this industry and how is it segmented)

- Organizational Behavior (i.e. bureaucratic, team environment)

- Globalization and International Marketing

IV. Before you go on the interview: research the corporation and your completed report should include the following information:

- Evaluate and Critique the Website: Design, focus, themes, philanthropy, image portrayed, anything you find interesting

- Statement (formal or informal) of corporation's philosophy or mission statement

- Chain-of-Command within the Corporation: Include a diagram, if available

- Communication Flow within the corporation, may add chart

- Physical Plant/s: size, location, function/ interesting facts

- Personnel: number of employees/ levels of management, labor, facilities, etc

- Financial Information (use public record or gather data for this from the person you interview if it is a privately held company) that shows the relationship of the company to the industry and to other like corporations

- Know the philanthropies that the industry supports

- Look for ways the Corporation "says" it is involve in Sustainability 


\section{Gather the follow information in your interview:}

\section{Profile the Interviewee:}

- Give Title and Formal job description / indicate the interviewee on the chain of command

- List and Evaluate the duties (areas of responsibility) of the interviewee

- Assess Business Protocol and Personal Appearance:

The Dress/Wardrobe Culture

Body Language - Non-verbal Messages

Signs of Confidence/Nervousness/Notes

Symbols of Power, Success, Competition

Discover the Facts:

- Ask for current copy of their résumé, if available, or ask for a short run-down of their job history

- Note how much communication is a part of their job function

- Learn what preparation they had for communication: high school, college, workshops, training

- Find out what they believe is the best preparation for communication in the business world and their profession.

- Request the individual to share what is most challenging about the kind of communication they do, and what is rewarding

- Explain methods they use to "think outside the box." Ask to what extent they can rely on forms for their communication

- Ask for and use, as part of the summary for this project, any special message the interviewee has for communicating in the business world

- List Professional Associations to which they belong and all the professional publications they read for business

- Discover what philanthropies that the interviewee embraces personally

Questions to Use for Discussion

- How did you locate your current position? (Networking, etc.)

- How did you prepare for your career interview?

- Is your undergraduate degree related to your current position?

- What skills do you have that help you the most?

- What skills do you not have that would help you in your career?

- How often are you evaluated in your position and how are you evaluated?

- How much crisis management is involved in your work/communication?

- What is your source for News and Current Events?

Use the following guidelines in the interview.

- Be prompt to arrive and prompt to exit

- Shake hands and wait to sit until you are invited

- Restate your purpose, briefly

- Be Organized

- Use small notebook, which looks professional, with all the questions written out - leave room to make notes or record responses

- Begin by establishing a rapport with the interviewee:

\footnotetext{
Specifically - set the context for the interview: "I am here to discover/learn some personal strategies you use in communication."

- Do not disagree or hold forth your own opinions.

- Let the expert do the talking.
} 
- Be prepared - know the person, know something about the person, i.e.: background, length of the time with corporation, personal likes or dislikes. Research or look for clues in office.

- Respect the interviewee's time limit. Stop within the time frame you set-up when you made the appointment.

- Check your understanding of what the interviewee is saying by occasionally paraphrasing the point the speaker is making.

VI. Assess each writing sample: Use terminology from the text and from class discussion.

- Identify the form of the Communication (sales letter, inquiry letter, etc.)

- Note the subject of correspondence

- Summarize the content briefly

- State the Occasion/Audience/Setting

- Indicate the Purpose: To Evoke, Persuade, or Entertain and explain how the purpose is achieved

- Describe the Method of Introduction: inductive or deductive

- Identify the tone and indicate what specific language is used to set tone, use quotes from the samples to support this

- Analyze the Conclusion: Logical or Psychological

- Evaluate the Organization - use specifics from text material to explain

- Determine the level of Language Usage

- Note the specifics of Style (courtesy and tact, the "you" attitude)

- Evaluate for Grammar-Mechanics

- Discuss Document Format: use of bullets, white space, paragraphing,

- Evaluate the letter head or other such features of format

- Write an Overall Impression of Professional Presentation.

VII. In the last section of the paper before the summary discuss the following:

- Career opportunity

- Required education and experience

- Role of communication

VIII. Final Presentation:

Present the material in a professional and business-like manner. All parts typed on good bond and presented in a plain manila folder. All parts of the report must follow the APA guidelines for the long report. A letter of transmittal should accompany this long report. Address the letter to the person directly responsible for assigning the project.

The pattern for organization of the report is title page, letter of transmittal, contents page, executive summary, report body which includes the samples of business correspondence with the assessment of each sample. Remember that each part of a long report is introduced before it is included in the report.

Include a copy of the thank-you letter at the end of the report. Please follow guidelines for writing formal business letters for this assignment. The copy of the thank-you letter with an addressed envelope should be included for review. The thank-you letter must be approved before mailing. You are to mail the letter once it is approved.

Make generous use of headings throughout the report. The body of the report is the information you gather in the interview, the collection of the five samples of writing, and the assessments you write. The sample writings, as all separate parts of a report, should be introduced, and the critiques should follow directly the samples. Please note special instruction for the organization of the writing samples.

Plan ahead and enjoy this project! 


\section{Professional Portfolio Evaluation}

6\% Elements of a Long Report (elements)

- Title/Title Page

- Contents Page

- Letter of Transmittal

- Executive Summary

- Introduction/Conclusion

- Body with at least three levels of headings

- Thank-you letter

4\% Professional Presentation

- Professional Appearance

- Bond Paper

- Manila Folder

- Correct Font/Manuscript Form

\section{$10 \%$ Organization of Material}

- APA Format and Mechanics

- Internal Citations/Documentation

- Reference List

- Headings

- Follow Directions

\section{5\% Research Evaluation}

- Organization of Material/complete research of topic

- Quality of Research/current and relevant data

- Amount of Research/Number of sources

\section{0\% Writing Quality}

- Language Usage

- Writing Style

- Grammar/Mechanics

- Content
500 points

(30 points)

(20 points)

(50 points)

(75 points)

(100 points)

(100 points)

$20 \%$ Assessment of Writing Samples

- Collect five samples of relevant business writing

- Use of Headings in writing assessment

- Demonstrate Knowledge of Rules of Business Correspondence

\section{0\% Personal Interview}

- Gathered In-depth Information

- Conducted Professional Interview

- Presented in dialogue or overview form with editorial observation

5\% Evaluation and Research of Career Path

- Forecast Information on Industry

- Forecast Information on Corporation

- Forecast on Individual Career Requirements
(25 points)

(100 points)
(25 points) 
NOTES 